\title{
META ANALISIS PLATFORM MEDIA DIGITAL RAMAH PENYANDANG DISABILITAS
}

\author{
${ }^{1}$ Albertus Magnus Prestianta \\ ${ }^{2}$ FX Lilik Dwi Mardjianto \\ ${ }^{3}$ Hargyo Tri Nugroho Ignatius \\ ${ }^{1,2}$ Program Studi Jurnalistik, ${ }^{3}$ Program Studi Sistem Komputer, Universitas Multimedia Nusantara \\ Email: ${ }^{1}$ albertus.prestianta@umn.ac.id, ${ }^{2}$ lilik@umn.ac.id, ${ }^{3}$ hargyo@umn.ac.id
}

\section{ARTICLE INFO}

\section{ABSTRACT}

Keywords:

Accessibility, WCAG 2.0,

Cyber Media, Disabled

People

\begin{abstract}
One of the main functions of mass media is providing information. At the same time, the access to information is everyone's right. Therefore, the mass media have to open the possibilities for people to access information, including disabled people. Act. Number 8 of 2016 concerning disabled people also mandates this right. The act will come into force in 2018, so various parties need to make various preparatory efforts, including conducting research. This study aims to map online news sites that are friendly and unfriendly to disabilities. To achieve this goal, researchers use standards in the Web Content Accessibility Guidelines (WCAG) to map online media in Indonesia that are friendly to access for disabled people. To obtain this information the researchers conducted a quantitative study of 62 cyber media sites in Indonesia by measuring the level of accessibility of the media to disabled people. The findings indicate that there are no cyber media sites in Indonesia that are friendly to access for disabled people. Sites like Riau24.com, Manadonews.co.id and Ayobandung.com are sites with the highest percentage of success among the 62 sites analyzed.
\end{abstract}

\section{PENDAHULUAN}

Internet dan teknologi digital telah membawa perubahan di berbagai aspek kehidupan manusia, salah satunya adalah aspek persebaran informasi dan komunikasi. Teknologi Informasi dan Komunikasi (TIK) yang diperkuat dengan konektivitas internet memungkinkan seseorang membuat, mengemas, dan menyebarkan informasi yang bersifat multimedia dalam waktu yang relatif singkat.

Indonesia saat ini sedang berada dalam gelombang tersebut. Salah satu faktor yang menyebabkan kondisi tersebut adalah tingkat penggunaan internet di Indonesia yang tinggi. Hasil survey yang dilakukan oleh Asosiasi penyelenggara Jasa Internet Indonesia (APJII) pada 2017 menunjukkan bahwa dari total 262 juta pendudukan di Indonesia, sebanyak 143,26 juta orang telah menggunakan intenet. Hal itu berarti lebih dari separuh penduduk Indonesia telah menggunakan internet untuk berbagai keperluan.

Dalam survey yang dilakukan setahun sebelumnya, APJII berhasil memetakan bahwa sebagian besar orang Indonesia menggunakan intenet untuk mencari informasi (25,3 persen, atau sebanyak 31,3 juta orang). Angka itu bahkan lebih banyak bila dibandingkan dengan jumlah orang yang menggunakan internet untuk keperluan pekerjaan (20,8 persen, atau 27,6 juta orang).

Kenyataan bahwa sebagian besar orang di Indonesia menggunakan internet untuk mencari informasi menjadi pemicu pertumbuhan berbagai layanan informasi berbasis internet. Website berita adalah salah satu bentuk layanan informasi berbasis internet. Berdasarkan data Dewan Pers, saat ini terdapat 70 ribu media daring di Indonesia yang menyedikan layanan informasi. Dari jumlah tersebut, terdapat 62 media daring yang terferifikasi administrasi dan faktual sebagai media daring yang melakukan kegiatan jurnalistik.

Kondisi ini relatif menggembirakan apabila dilihat dari aspek kebebasan untuk memroduksi dan mengonsumsi informasi. Artinya, publik mendapatkan kebebasan untuk menjadi produsen konten, ataupun menjadi konsumen informasi dalam bentuk produk-produk jurnalistik. Sebagai konsumen, publik memiliki kesempatan untuk memilih berbagai bntuk informasi yang ditayangkan di ribuan website yang bisa diakses secara mudah. Namun, apabila dilihat dari kesamaan hak untuk 
mendapatkan informasi, kondisi tersebut belum tentu menggembirakan. Artinya, tidak setiap kelompok masyarakat mendapatkan porsi atau kesempatan yang sama dalam mendapatkan informasi. Salah satu kelompok masyarakat yang rentan mengalami hambatan dalam mendapatkan informasi melalui website adalah penyandang disabilitas.

Undang-undang nomor 8 tahun 2016 tentang Penyandang Disabilitas menyatakan penyandang disabilitas adalah setiap orang yang mengalami keterbatasan fisik, intelektual, mental, dan/atau sensorik dalam jangka waktu lama yang dalam berinteraksi dengan lingkungan dapat mengalami hambatan dan kesulitan untuk berpartisipasi secara penuh dan efektif dengan warga negara lainnya berdasarkan kesamaan hak. Berdasarkan definisi tersebut, dimensi keterbatasan para penyandang disabilitas sangat luas. Artinya penyandang disabilitas tidak hanya memiliki keterbatasan fisik (pengelihatan, pendengaran, morotik, dan lainnya), namun juga keterbatasan intelektual dan mental.

Jumlah penyandang disabilitas di Indonesia tidak bisa dibilang sedikit. Sebagai ilustrasi, latar belakang ini akan fokus pada pemaparan jumlah penyandang disabilitas yang memiliki keterbatasan penglihatan dan pendengaran.

Hasil Survey Penduduk Antar Sensus (SUPAS) 2015 yang dilakukan oleh Badan Pusat Statistik (BPS) menunjukkan bahwa sebanyak 270.471 orang di Indonesia yang berusia di atas 10 tahun yang tidak bisa melihat sama sekali. Angka ini menjadi semakin tinggi apabila ditambahkan dengan jumlah orang Indonesia yang mengalami gangguan pengelihatan kategori banyak (1.502.819 orang) dan kategori sedikit (11.447.950 orang). Angka-angka tersebut adalah jumlah penduduk Indonesia yang mengalami kesulitan melihat, baik laki-laki maupun perempuan, serta tersebar di pedesaan dan perkotaan. Uraian lebih rinci mengenai hal tersebut bisa dilihat di dalam tabel berikut ini.

Apabila merujuk pada kriteria yang dibuat oleh BPS tentang usia produktif (15-64 tahun), maka terdapat 131.450 orang Indonesia yang sama sekali tidak bisa melihat pada saat mereka seharusnya bisa melakukan banyak hal tanpa mengalami kesulitan, termasuk dalam mengakses informasi.

Sementara itu, angka gangguan pendengaran juga relatif banyak. Berdasarkan data SUPAS 2015, jumlah penduduk Indonesia yang berusian di atas 10 tahun dan tidak bisa mendengar sama sekali mencapai 178.613 orang. Angka ini lebih sedikit bila dibandingkan dengan jumlah penduduk Indonesia yang berusia di atas 10 tahun dan mengalami gangguan pendengaran kategori "banyak" (1.180.722 orang) dan kategori "sedikit" (5.593.462 orang). Sementara itu, jumlah penduduk usia produktif (15-64 tahun) yang tidak bisa mendengar sama sekali berjumlah 97.340 orang. Rincian jumlah penduduk Indonesia yang mengalami gangguan pendengaran bisa dilihat di tabel berikut ini.

Kelompok penyandang disabilitas juga memiliki hak yang dijamin oleh aturan hokum. Salah satu hak penyandang disabilitas yang dilindungi oleh undang-undang adalah hak untuk mendapatkan informasi. Pasal 24 Undang-undang Penyandang Disabilitas menegaskan bahwa penyandang disabilitas memiliki hak untuk mendapatkan informasi dan berkomunikasi melalui media yang mudah diakses. Berdasarkan hal tersebut, dapat dikatakan bahwa para penyandang disabilitas memiliki hak untuk mendapatkan informasi di era internet dan digital saat ini melalui berbagai website berita yang mudah diakses.

Hal ini mendorong tim peneliti untuk mengukur tingkat aksesibilitas website berita yang ada di Indonesia bagi para penyandang disabilitas. Untuk melakukan hal tersebut, peneliti menggunakan Web Content Accessibility Guidelines (WCAG) yang dikembangkan oleh World Wide Web Consortium (W3C).

W3C adalah sebuah konsorsium yang fokus pada berbagai program untuk mendorong dan meningkatkan aksesibilitas website, teriutama bagi penyandang disabilitas (https://www.w3.org/WAI/about/). Salah satu gerakan nyata W3C dalam melakukan hal itu adalah meluncurkan Web Accessibility Initiative (WAI), yang melahirkan Web Content Accessibility Guidelines (WCAG), sebuah panduan pengukuran tingkat aksesibilitas website.

Berdasarkan uraian latar belakang pada poin sebelumnya, penelitian ini hendak mengetahui bagaimana tingkat aksesibilitas website berita di Indonesia bagi para penyandang disabilitas.

Penelitian ini bertujuan untuk mengetahui sejauh mana tingkat aksesibilitas situs media berita di Indonesia bagi penyandang disabilitas. Hal ini didasari oleh asumsi bahwa media digital memberikan lebih banyak kemudahan bagi siapa saja untuk mengakses informasi tanpa terkecuali para 
penyandang disabilitas. Oleh karenanya, peneliti menganalisis media digital di Indonesia dengan mengukur tingkat aksesibilitas bagi penyandang disabilitas, khususnya tuna rungu dan tuna netra.

Penelitian ini akan memberikan perspektif bagi khalayak khususnya praktisi media terkait tingkat aksesibilitas bagi publik. Melalui penelitian ini, khalayak dapat mengetahui seberapa ramah situs berita yang ada di Indonesia bagi publik yang mengkonsumsinya tanpa terkecuali para penyandang disabilitas. Dengan adanya penelitian ini, diharapkan media massa digital memperhatikan para penyandang disabilitas dengan menyajikan konten berita yang dapat diakses oleh mereka.

\section{TINJAUAN PUSTAKA}

\subsection{Studi tentang disabilitas}

Tidak semua orang terlahir lengkap dengan kondisi fisik dan mental yang sempurna. Orang kerap memberikan cap bagi mereka yang kurang secara fisik dan mental sebagai orang cacat. Kata cacat selalu diasosiasikan dengan hal negatif. Orang cacat kerap mendapat perlakukan berbeda dengan kebanyakan orang normal. Stereotip tidak mampu, tidak berguna dan dipandang sebelah mata adalah label yang melekat pada mereka yang memiliki keterbatasan.

Konvensi Hak Asasi Penyandang Disabilitas oleh PBB menggunakan kata disabilitas (disability) bagi mereka yang terkendala fisik dan mental. Oleh karenanya individu yang memiliki kekurangan seperti tidak dapat mendengar, tidak dapat berbicara, keterbelakangan mental dan lain sebagainya disebut sebagai penyandang disabilitas atau difabel.

Penelitian terkait penyandang disabilitas bukanlah sebuah hal yang baru. Dalam beberapa dekade silam, penelitian yang ada hubungannya dengan penyandang disabilitas telah dilakukan oleh berbagai rumpun ilmu.

Xiaoming (2004) melakukan evaluasi terhadap sejumlah website yang memuat informasi tentang kesehatan dengan menggunakan matriks Web Accessibility Barriers (WAB). Hasilnya, dari 108 situs yang dianalisis ia dapat memisahkan situs mana yang dapat diakses dan situs mana yang tidak ramah untuk diakses oleh penyandang disabilitas. Dalam temuannya ia menyebutkan bahwa website pemerintah dan lembaga pendidikan di Amerika Serikat memiliki skor WAB yang terendah diantara situs lainnya.

Jaeger (2006) melakukan penelitian terkait disabilitas dalam lingkup manajemen informasi dan kebijakan. Ia menilai bahwa pemerintah Amerika Serikta kurang memperhatikna penyandang disabilitas dalam mengembangkan teknologi informasi dan komunikasi. Akhirnya banyak penyandang disabilitas yang tidak dapat mengakses informasi kecuali ada alat bantu yang dikembangkan untuk memfasilitasi mereka agar dapat mengakses informasi. Menurut Jaeger (2006: 170), Undang-Undang Rehabilitas tahun 1998, bagian 508, mengharuskan setiap lembaga pemerintahan di Amerika Serikat memiliki situs yang dapat diakses oleh penyandang disabilitas. Dalam penelitiannya, Jaeger studi multi metode, yang berpusat pada pengguna situs pemerintah dengan membahas kompleksitas permasalahan aksesibilitas dan alasan-alasan kenapa situs-situs pemerintah kurang memperhatikan pengguna difabel.

Cooper (2007) dalam penelitiannya menegaskan bahwa era Web 2.0 dan Semantic Web akan memberi kemudahan bagi siapa saja untuk mengakses informasi dan memahami makna pesan. Menurutnya, teknologi baru memiliki kemampuan untuk mengatasi kendala yang dihadapi. Cooper berargumentasi bahwa Web 2.0 dan Semantic Web bermanfaat untuk aksesibilitas.

Small, J., Schallau, P., Brown, K., \& Appleyard, R. (2005) melakukan analisis terhadap individu dengan keterbatasan kognitif (developmental cognitive disabilities-DCD)saat mengakses situs yang sudah memenuhi kriteria W3C Accessibility. Empat hal yang dijadikan sebagai faktor yang analis adalah situation awareness, spatial awareness, task-set switching, dan anticipated system response. Hasil temuan mereka menunjukkan bahwa pedoman aksesibilitas W3C belum ramah untuk diakses bagi penyandang DCD.

Penelitian lain yang menjadi dasar penelitian ini adalah penelitian yang dilakukan Zeng dan Parmanto (2004). Keduanya melakukan penelitian dengan menganalisis Web Accessibility Barriers (WAB) terhadap 108 situs yang memuat informasi tentang kesehatan. Zeng dan Parmanto memfokuskan penelitian dengan menginvestigasi apakah perbedaan antara skor WAB dengan sejumlah fungsi-fungsi yang dimiliki oleh situs. Selain itu mereka juga mengevaluasi hubungan antara WAB dengan situs dalam ranking Alexa dan Google Page Rank. Hasilnya, tidak ada situs yang sepenuhnya ramah untuk diakses oleh penyandang disabilitas, semua situs yang dianalisis memiliki 
pelanggaran fungsi alias tidak sesuai dengan pedoman WAB. Menurutnya, situs informasi kesehatan pemerintah dan pendidikan memiliki nilai aksesibilitas yang lebih baik daripada situs dalam kategori lainnya. Terdapat hubungan yang signifikan antara skor WAB dengan popularitas situs.

\subsection{Penelitian Disabilitas di Indonesia}

Thohari (2014) dalam penelitiannya menggambarkan penyandang disabilitas di kota Malang sebagai orang yang tidak sempurna "unperfect people" oleh karenanya mereka penyandang disabilitas harus bersekolah ditempat yang khusus. Temuan lain dalam penelitiannya menjelaskan bahwa fasilitas umum (fasum) di Malang tidak ramah bagi penyandang disabilitas. Berdasarkan data yang dia peroleh, seluruh fasum di kota Malang tidak dapat diakses oleh penyandang disabilitas.

Utami, Raharjo dan Apsari (2018) melakukan penelitian terkait aksesibilitas penyandang tunadaksa dalam mengakses pendidikan di Institut Teknologi Bandung (ITB) di Jatinangor. Hasil riset Utami, dkk. menunjukkan bahwa tidak semua bangunan milik institusi belum sesuai standar yang ada (keselamatan, kemudahaan, kegunaan dan kemandirian) untuk diakses oleh penyandang tunadaksa.

Penelitian Thohari (2014) dan Utami, dkk. (2018) sama-sama berfokus pada aksesibilitas. Titik tekan permasalahan dalam penelitian tersebut berkaitan dengan fungsi tubuh dan struktur tubuh. Padahal tantangan yang dihadapi penyandang disabilitas bukan hanya terkait fungsi tubuh dan struktur tubuh yang tidak sempura, ada dari mereka yang juga menghadapi tantangan dalam beraktivitas dan berpartisipasi dalam masyarakat sosial.

Penelitian yang dilakukan Utami (2015) semakin menegaskan bahwa penyandang disabilitas punya hak yang sama dalam mengakses informasi. Dalam catatannya dia menyebutkan Universitas Islam Negeri Sunan Kalijaga Jogjakarta (UIN SUKA) memiliki fasilitas khusus bagi tunanetra yakni Difabel Cornor (DC). Fasilitas tersebut menyediakan alat bantu agar tunanetra dapat mengakses koleksi bacaan yang dimiliki perpustakaan. Menurut Utami kemajuan teknologi seharusnya memudahkan akses informasi bagi semua bukan memperlebar kesenjangan akses informasi.

Dari seluruh pemaparan penelitian terdahulu yang pernah dilakukan, penelitian tentang disabilitas di Indonesia lebih banyak menitikberatkan pada aksesibilitas fisik terkait fasilitas umum. Penelitian yang mengkaji tentang aksesibilitas penyandang disabilitas terhadap situs media di Indonesia belum banyak dilakukan. Berdasarkan pemaparan di atas, peneliti melihat ada potensi untuk melakukan penelitian terkait aksesibilitas situs media di Indonesia.

Berdasarkan pemaparan kondisi di atas, peneliti merasa perlu untuk menganalisis situs media di Indonesia, apakah ramah atau tidak bagi penyandang disabilitas, mengingat penyandang disabilitas di Indonesia memiliki hak yang sama dengan orang normal dalam mendapatkan informasi dan berkomunikasi melalui media yang mudah diakses.

\section{METODE PENELITIAN}

\subsection{Prosedur Penelitian Meta-analisis}

Penelitian ini berusaha untuk memetakan media digital atau online yang mengakomodir hakhak penyandang disabilitas dalam hal berekspresi, berkomunikasi dan memperoleh informasi. Metode yang digunakan adalah meta-analisis atau bisa disebut sebagai research synthesis atau quantitative reviewing (Johnson, dkk. 2008: 312 ).

Dalam melakukan penelitian berbasis meta analisis, Johnson, dkk (2008: 315) menjelaskan terdapat tujuh langkah yang menjadi prosedur melakukan penelitian: 1). Mendefinisikan pertanyaan (defining the question), 2). Menetapkan batas-batas sampel penelitian (Setting Boundaries for The Sample of Studies), 3). Menemukan literatur yang relevan (locating the literature of relevant studies), 4). Melakukan coding (coding studies for their distinctive characteristics), 5). Memperkirakan ukuran berdasarkan matrik yang sudah distandarisasi (estimating the magnitude effect in each study), 6). Menganalisis data, dan 7). Menginterpretasikan dan menampilkan hasil temuan.

\subsection{Unit Analisis}

Unit analisis menurut Eriyanto (2011: 61) terbagi dalam tiga besar, yakni unit sampel, unit pencatatan, dan unit konteks. Unit sample adalah bagian dari objek yang dipilih oleh peneliti untuk didalami. Unit sample ditentukan oleh topik dan tujuan dari riset. Lewat unit sampel, peneliti dapat secara tegas menentukan mana konten yang diteliti dan yang tidak diteliti. 
Unit pencatatan adalah bagian atau aspek yang menjadi dasar dalam pencatatan dan analisis. Isi atau topik memiliki unsur atau elemen, unsur atau elemen ini harus didefinisikan sebagai dasar peneliti melakukan pencatatan. Peneliti harus memilih bagian mana yang akan dicatat.

Sementara unit konteks adalah konteks apa yang diberikan oleh peneliti untuk memahami atau memberi arti pada hasil pencatatan. Unit konteks dapat berupa konteks yang sesuai dengan topik penelitian atau konteks lain yang mempengaruhi.

Dalam penelitian ini yang menjadi unit sampel adalah semua media massa siber nasional yang telah terverifikasi faktual dan administrasi oleh dewan pers.

\subsection{Populasi dan sampel}

Populasi dalam penelitian ini adalah media massa online nasional dengan kriteria yang disusun. Teknik pengambilan sampel yang digunakan adalah sampel bertujuan atau purposive sampling. Hal ini didasarkan pada tujuan penelitian dan keterkaitannya dengan topik penelitian. Kriteria yang digunakan adalah media massa online nasional yang telah lulus verifikasi administrasi dan faktual oleh dewan pers sejumlah 62 situs. Sebagai pembanding, digunakan 3 media massa online nasional dengan trafik tertinggi menurut Alexa.com dan telah lolos verifikasi dewan pers.

\subsection{Teknik pengumpulan}

Pengambilan data ini dilakukan pada tanggal 18 s.d 22 Juni 2018 setiap pukul 10.00-12.26 pada laptop tunggal dengan spesifikasi prosesor Intel Core i7-2620 @ 2.70Ghz, RAM 8.00 GB, dan sistem operasi Windows 10 Pro.

Data dikumpulkan dengan menganalisis tampilan utama (home page atau landing page) dari setiap media massa online nasional menggunakan browser Mozilla Firefox 56.0 (64 bit) yang dilengkapi extension OAA Accessibility Extension 0.9.2.1-signed. OAA Accessibility Extension 0.9.2.1-signed dikembangkan menggunakan library OpenAjax yang akan muncul sebagai sidebar pada browser Firefox. Ekstensi ini mampu mengevaluasi kesesuaian halaman web terhadap WCAG 2.0 berdasarkan elemen HTML yang ditemukan.

\section{HASIL DAN PEMBAHASAN}

Hasil analisis menunjukkan temuan yang menarik. Dari 62 situs web media terverifikasi aktual dan administrasi yang dianalisis, Riau24.com, Manadonews.co.id dan Ayobandung.com menempati posisi tiga teratas dalam hal persentase kesesuaian WCAG 2.0. Berdasarkan tabel 4.1, Manadonews.co.id dan Riau24.com sama-sama memiliki \%passed tertinggi yakni 87\%, sementara Ayobandung.com sebesar $82 \%$. Semakin tinggi nilai persentase kesesuaian artinya konten dalam situs web tersebut semakin mudah diakses oleh penyandang disabilitas, khususnya mereka yang tunanetra atau penglihatannya terbatas, tunarungu atau pendengaran pekak.

Tabel 4.1 Peringkat Persentase Kesesuaian WCAG 2.0

\begin{tabular}{llccccr}
\hline Peringkat & \multicolumn{1}{c}{ Nama Media } & $\begin{array}{c}\text { Persentase } \\
\text { item } \\
\text { konten } \\
\text { sesuai } \\
\text { WCAG }\end{array}$ & $\begin{array}{c}\text { Persentase } \\
\text { item } \\
\text { konten } \\
\text { melanggar } \\
\text { WCAG }\end{array}$ & $\begin{array}{c}\text { Persentase } \\
\text { jumlah } \\
\text { Konten* }\end{array}$ & $\begin{array}{c}\text { Persentase } \\
\text { konten cek } \\
\text { manual** }\end{array}$ & $\begin{array}{c}\text { Total } \\
\text { seluruh } \\
\text { Konten*** }\end{array}$ \\
\hline 1 & Riau24.com & $87.20 \%$ & $12.80 \%$ & $49 \%$ & $51 \%$ & \\
2 & manadonews.co.id & $87.20 \%$ & $12.80 \%$ & $48 \%$ & $52 \%$ & 1859 \\
3 & Ayobandung.com & $81.60 \%$ & $18.40 \%$ & $61 \%$ & $39 \%$ & 819 \\
4 & Batamtoday.com & $80.40 \%$ & $19.60 \%$ & $68 \%$ & $32 \%$ & 2084 \\
5 & goriau.com & $77.80 \%$ & $22.20 \%$ & $20 \%$ & $80 \%$ & 1660 \\
6 & timesindonesia.co.id & $76.80 \%$ & $23.20 \%$ & $48 \%$ & $52 \%$ & 564 \\
7 & tribunjambi.com & $76.20 \%$ & $23.80 \%$ & $49 \%$ & $51 \%$ & 1882 \\
8 & metrotvnews.com & $76.00 \%$ & $24.00 \%$ & $34 \%$ & $66 \%$ & 1170 \\
\hline
\end{tabular}




\begin{tabular}{|c|c|c|c|c|c|c|}
\hline Peringkat & Nama Media & $\begin{array}{c}\text { Persentase } \\
\text { item } \\
\text { konten } \\
\text { sesuai } \\
\text { WCAG }\end{array}$ & $\begin{array}{c}\text { Persentase } \\
\text { item } \\
\text { konten } \\
\text { melanggar } \\
\text { WCAG }\end{array}$ & $\begin{array}{c}\text { Persentase } \\
\text { jumlah } \\
\text { Konten* }\end{array}$ & $\begin{array}{c}\text { Persentase } \\
\text { konten cek } \\
\text { manual** }\end{array}$ & $\begin{array}{c}\text { Total } \\
\text { seluruh } \\
\text { Konten**** }\end{array}$ \\
\hline 9 & Netralnews.com & $75.60 \%$ & $24.40 \%$ & $53 \%$ & $47 \%$ & 468 \\
\hline 10 & Tirto.id & $75.40 \%$ & $24.60 \%$ & $56 \%$ & $44 \%$ & 1071 \\
\hline 12 & tribun-medan.com & $74.80 \%$ & $25.20 \%$ & $45 \%$ & $55 \%$ & 1294 \\
\hline 11 & sulutdaily.com & $74.80 \%$ & $25.20 \%$ & $19 \%$ & $81 \%$ & 759 \\
\hline 13 & suara.com & $73.60 \%$ & $26.40 \%$ & $51 \%$ & $49 \%$ & 1903 \\
\hline 14 & tribunjateng.co & $73.60 \%$ & $26.40 \%$ & $47 \%$ & $53 \%$ & 1209 \\
\hline 15 & obsessionnews.com & $73.40 \%$ & $26.60 \%$ & $45 \%$ & $55 \%$ & 1268 \\
\hline 16 & bisnis.com & $73.00 \%$ & $27.00 \%$ & $44 \%$ & $56 \%$ & 1109 \\
\hline 17 & kabarmakassar.com & $72.80 \%$ & $27.20 \%$ & $58 \%$ & $42 \%$ & 430 \\
\hline 18 & batamclick.com & $72.60 \%$ & $27.40 \%$ & $50 \%$ & $50 \%$ & 369 \\
\hline 19 & sulutnews.com & $71.80 \%$ & $28.20 \%$ & $48 \%$ & $52 \%$ & 824 \\
\hline 20 & telegrafnews.co & $71.60 \%$ & $28.40 \%$ & $42 \%$ & $58 \%$ & 838 \\
\hline 21 & Covesia.com & $71.60 \%$ & $28.40 \%$ & $28 \%$ & $72 \%$ & 717 \\
\hline 22 & minangsatu.com & $71.00 \%$ & $29.00 \%$ & $51 \%$ & $49 \%$ & 770 \\
\hline 23 & jurnalsumatra.com & $70.60 \%$ & $29.40 \%$ & $34 \%$ & $66 \%$ & 1894 \\
\hline 24 & marwahkepri.com & $70.60 \%$ & $29.40 \%$ & $25 \%$ & $75 \%$ & 1141 \\
\hline 25 & wartakepri.co.id & $70.40 \%$ & $29.60 \%$ & $42 \%$ & $58 \%$ & 1378 \\
\hline 26 & bunaken.co.id & $70.20 \%$ & $29.80 \%$ & $49 \%$ & $51 \%$ & 1070 \\
\hline 27 & arah.com & $68.80 \%$ & $31.20 \%$ & $50 \%$ & $50 \%$ & 844 \\
\hline 28 & suaramerdeka.com & $68.00 \%$ & $32.00 \%$ & $60 \%$ & $40 \%$ & 698 \\
\hline 29 & kompas.com & $67.80 \%$ & $32.20 \%$ & $55 \%$ & $45 \%$ & 1008 \\
\hline 30 & viva.co.id & $67.80 \%$ & $32.20 \%$ & $56 \%$ & $44 \%$ & 1001 \\
\hline $31-62$ & \multicolumn{6}{|c|}{ Sampai 62 situs yang diteliti.... } \\
\hline
\end{tabular}

*persentase jumlah konten pada situs web yang berhasil dianalisi menggunakan alat bantu Open Ajax Accessibility Extension

**Persentase jumlah konten pada situs web yang perlu dianalisis secara manual (mengandalkan penilaian manusia)

***Total seluruh item konten yang tersedia pada situs web

Jika dihitung berdasarkan rata-rata tingkat kelulusan, dari 62 situs yang dianalisis rata-ratanya sebesar 62,4\%. Gambar 4.1 menunjukkan bahwa ada 58\% dari seluruh situs web yang posisinya diatas rata-rata, sementara sisanya di bawah rata-rata kesesuaian. Fakta ini menunjukkan bahwa situs web media yang peneliti analisis sebagian besar sudah sesuai dengan pedoman WCAG. Peneliti merasa, media massa bisa meningkatkan kinerja situs web agar semakin ramah bagi penyandang disabilitas khususnya tunanetra, tunarungu atau pendengaran pekak. 


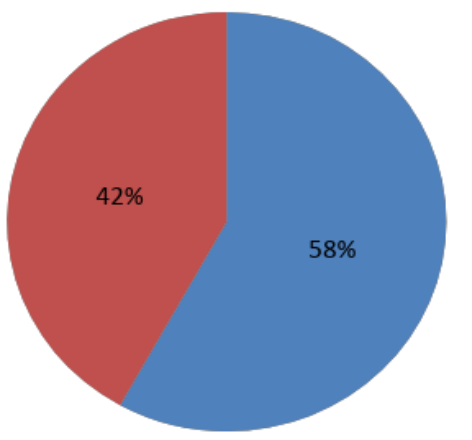

Di atas rata-rata

Di bawah rata-rata

Gambar 4.1 Jumlah situs web di atas rata-rata kesesuaian

Berdasarkan data hasil analisis ditemukan bahwa Cumicumi.com adalah media dengan situs web yang paling banyak menyediakan konten. Tercatat sebanyak 2.687 item yang tersedia dalam situs website tersebut. Dari total item, 64\% bisa dianalisis sesuai pedoman WCAG dengan menggunakan alat bantu Open Ajax Accessibility Extension, sementara sisanya harus dilakukan pengecekan secara manual dengan melibatkan penilaian manusia. Mengacu pada posisi peringkat kesesuaian konten dengan pedoman WCAG, Cumicumi.com menduduki posisi 35 dari 62 dengan persentase kesesuaian $64 \%$ dengan persentase cek manual $36 \%$. Cumicumi.com masih sedikit di atas rata-rata kesesuaian $62,4 \%$.

Di sisi yang lain, Batamclick.com menyajikan item konten sebanyak 369 item, yang paling sedikit dari 62 situs web lainnya. Namun, tingkat kesesuaian item dalam situs web Batamclick.com dengan WCAG lebih baik dari Cumicumi.com. Batamclick.com berada di posisi 18 dengan persentase kesesuaian konten terhadap pedoman WCAG sebesar 72,6\% dengan persentase cek manual $50 \%$.

Peneliti menilai bahwa yang paling penting adalah persentase kesesuaian dengan pedoman WCAG. Banyak atau sedikit jumlah item konten yang tersaji pada situs web masing-masing bukanlah faktor utama, sebab yang terpenting adalah seberapa ramah konten yang tersedia bagi semua orang termasuk masyarakat difabel, terkhusus mereka yang tidak bisa melihat dan tidak bisa mendengar.

Fakta lain yang juga menarik untuk diketahui adalah terkait aspek pelanggaran (violations). Data dari tabel 1, menunjukkan bahwa item konten tabloidjubi.com adalah yang paling tidak sesuai dengan pedoman WCAG. Tercatat $71,2 \%$ item konten pada situs web media massa ini melanggar ketentuan WCAG 2.0 dengan persentase konten yang harus dicek manual 55\%. Fakta-fakta tersebut membuat tabloidjubi.com berada diposisi paling bawah, 62 dari 62 .

Jika dilihat secara harian, 62 situs web media massa yang dianalisis nampak tidak ada perubahaan yang berarti. Persentase kesesuaian terhadap WCAG cenderung statis selama lima hari (18 Juni-22 Juni). Pada gambar 4.2 dapat dilihat pergerakan rata-rata harian 62 situs web dalam kategori persentase kelulusan. Pada gambar tersebut juga terlihat tiga situs web yang menduduki posisi teratas. Secara bersamaan gambar 4.2 juga memperlihatkan posisi dan pergerakan dua situs web terendah persentase kesesuaian dengan WCAG. Empat dari Kelima situs web tidak menunjukkan perubahan yang signifikan, cenderung landai. Sementara gerakan perubahan yang menonjol ditunjukkan oleh situs web tabloidjubi.com. Terjadi penurunan persentase kesesuaian yang signifikan pada hari pertama ke hari kedua, setelahnya melandai dan konsisten pada posisi kurang dari $30 \%$. 


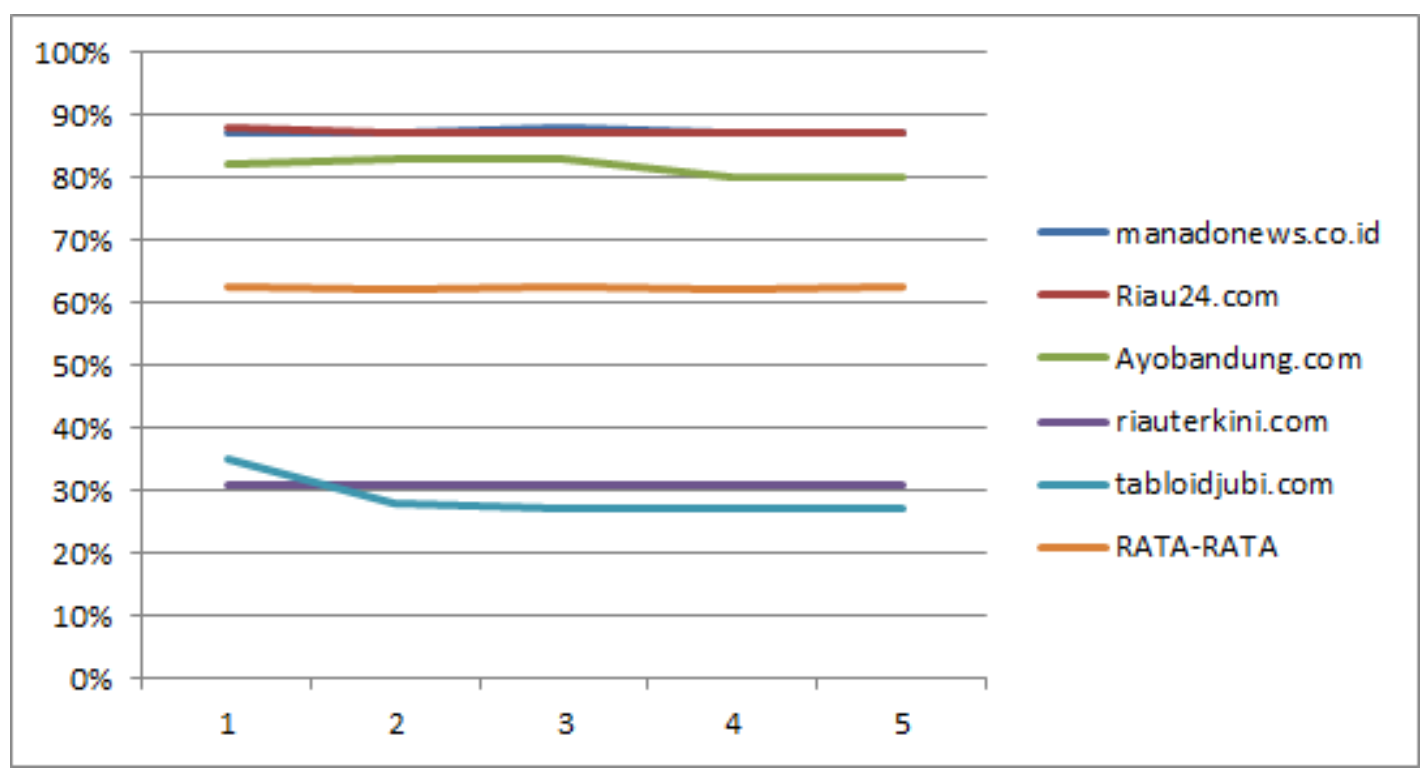

Gambar 4.2 Persentase kesesuaian harian 3 situs web teratas, rata-rata dan 2 terbawah

Fakta lain yang juga menarik untuk dibahas adalah jumlah ketidaksesuaian atau pelanggaran dengan WCAG (lihat gambar 4.3). Ada tiga situs web yang jumlah ketidaksesuaian tertinggi, yakni tabloidjubi.com, cumi-cumi.com dan bola.com. Jika dilihat pergerakan selama lima hari cumicumi.com dan bola.com bergerak landai pada angka pelanggaran tinggi. Perubahan signifikan terlihat pada tabloidjubi.com pada hari pertama dan kedua. Terjadi lonjakan yang eksponensial, sebesar 51\% kenaikan dari 715 pelanggaran menjadi 1.078 pelanggaran. Setelahnya, pada hari kedua hingga kelima tidak nampak adanya perubahan atau perbaikan. Jika dilihat berdasarkan pergerakan rata-rata pelanggaran, posisi ketiga situs web media tersebut berada jauh di atas garis rata-rata harian. Sedangkan, dua situs web yaitu sulutdaily.com dan goriau.com berada di bawah garis rata-rata, cenderung mendekati nol. Ini artinya sulutdaily.com dan goriau.com menunjukkan performa yang baik sebab tidak terdapat banyak pelanggaran atau ketidaksesuaian dengan WCAG.

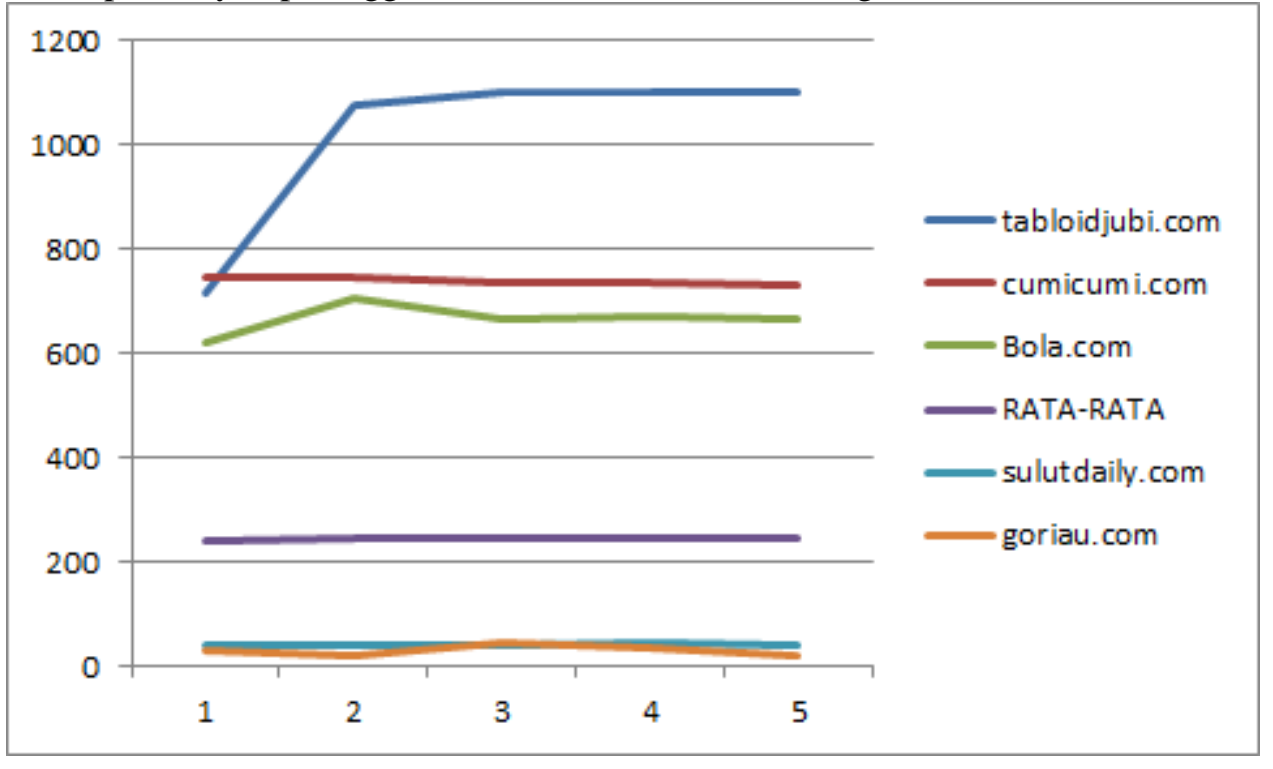

Gambar 4.3 Jumlah pelanggaran harian terbanyak terhadap WCAG 5 situs web

Pada kasus gambar 4.4, metrotvnews.com, tabloidjubi.com dan jurnalsumatra.com adalah situs web dengan jumlah item cek manual tertinggi. Terjadi lonjakan item cek manual yang signifikan pada Tabloidjubi.com di hari pertama ke hari kedua, Sementara metrotvnews.com dan 
jurnalsumatra.com melandai. Kabarmakassar.com dan uzone.id adalah situs web dengan item cek manual paling sedikit. Posisi kedua situs web tersebut berada jauh di bawah garis rata-rata.

Instruksi cek manual muncul ketika alat bantu analisis Open Ajax Accessibility Extension tidak mampu memberikan penilaian sesuai atau tidak sesuai terhadap item konten yang disajikan oleh situs web tertentu. Ketika dihadapkan pada hal ini, evaluator tidak bisa memberikan penilaian terhadap kondisi item konten yang tersaji pada situs web. Bila kondisi ini terjadi, maka ada dua kemungkinan jawaban. Pertama, munculnya jumlah item yang harus dicek manual mengindikasikan bahwa elemen HTML yang dipakai oleh situs web tertentu melampaui standar WCAG. Atau sebaliknya, bisa jadi ada kesalahan dalam penulisan elemen yang tidak sesuai dengan standar World Wide Web Consorsium (W3C).

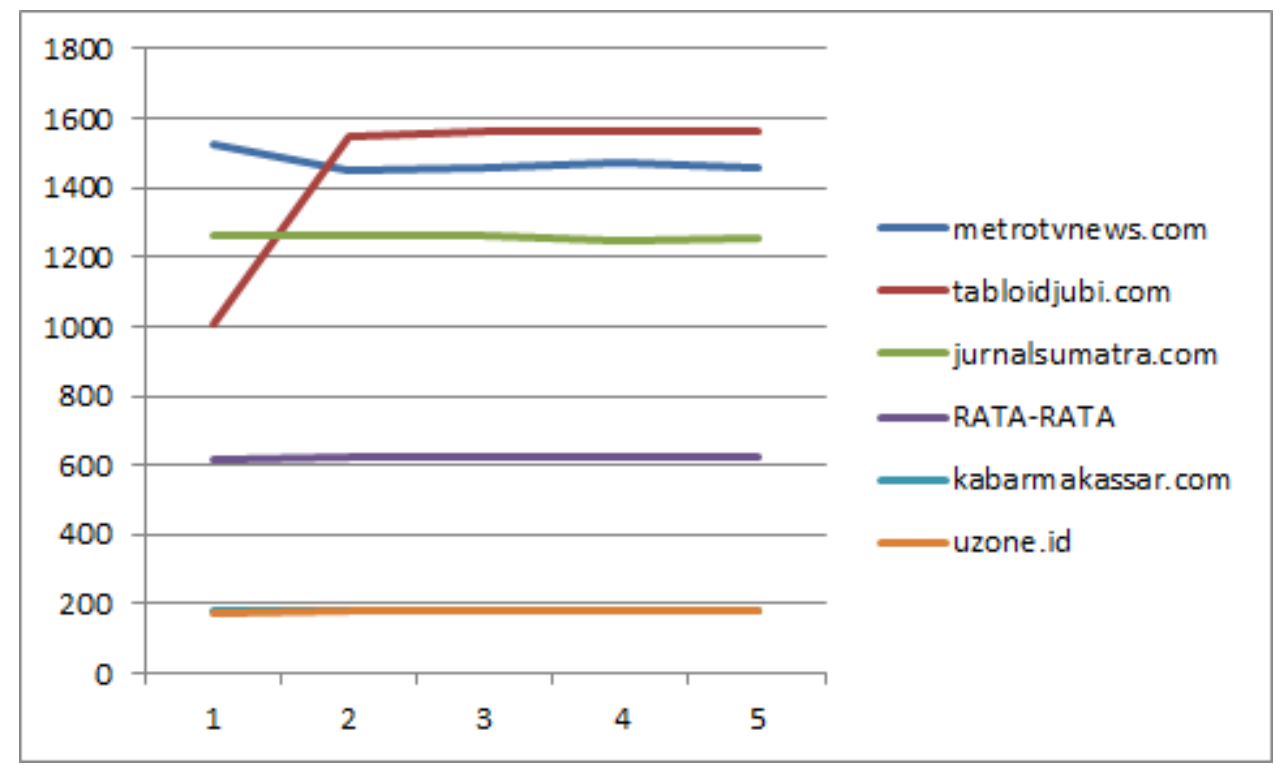

Gambar 4.4 Jumlah item konten cek manual harian terbanyak 5 situs web

Dari gambar 4.2 dan 4.3, tabloidjubi.com adalah yang paling rendah persentase kesesuaian terhadap WCAG dengan rata-rata persentase $28,8 \%$ dan paling banyak pelanggarannya terhadap WCAG dengan rata-rata pelanggaran sebanyak 849 item konten. Disaat bersamaan tabloidjubi.com adalah salah satu situs web dengan angka cek manual tertinggi dengan rata-rata manual cek sebanyak 1.473 item konten atau sebanyak 55\% dari rata-rata total item konten yang tersaji pada situs web.

\subsection{Posisi Media Arus Utama Terkait Pedoman WCAG}

Berdasarkan informasi yang tersaji di alexa.com, tribunnews.com menduduki posisi pertama untuk kategori media massa digital, diikuti detik.com pada posisi kedua, liputan6.com pada posisi tiga, kompas.com pada posisi empat dan sindonews.com pada posisi kelima. Namun, berdasarkan data dewan pers tribunnews.com dan sindonews.com tidak masuk dalam 62 media siber terverifikasi aktual dan administrasi. Untuk itu, pada penelitian ini detik.com, liputan6.com dan kompas.com kami sebut sebagai media arus utama yang terverifikasi aktual dan administrasi oleh dewan pers dan merupakan media yang paling banyak dikunjungi atau diakses oleh masyarakat Indonesia.

Pada gambar 5, posisi kompas.com dan detik.com berada sedikit di atas garis rata-rata persentase kesesuaian dengan pedoman WCAG. Sementara, liputan6.com berada di bawah posisi garis rata-rata. Hal ini menunjukkan bahwa item konten yang disajikan liputan6.com dalam situsnya sebagian besar berada masih jauh dari rata-rata kesesuaian dengan pedoman WCAG. 


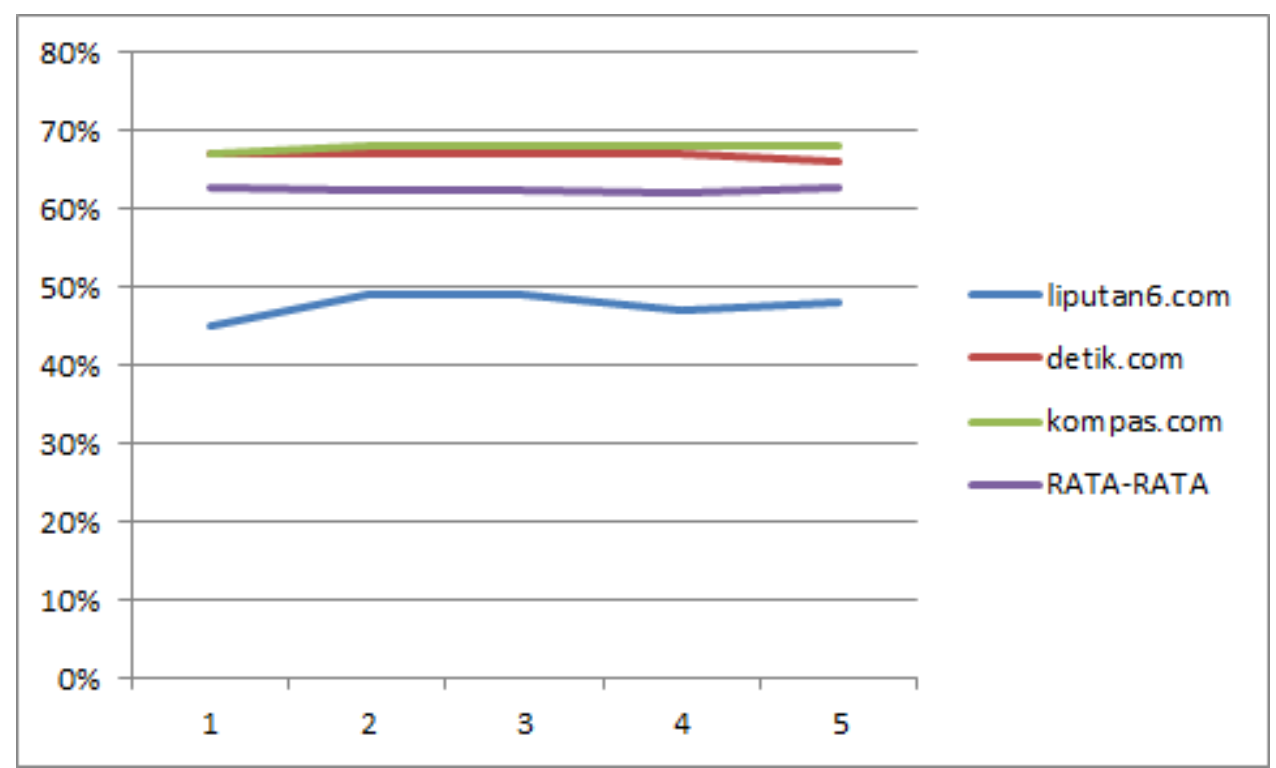

Gambar 4.5 Persentase kesesuaian 3 situs web media teratas versi Alexa.com

Kondisi yang terlihat pada gambar 5 sejalan dengan informasi yang tersaji pada gambar 6 . Berdasarkan informasi pada gambar 6, liputan6.com adalah situs web dengan jumlah pelanggaran konten terhadap pedoman WCAG yang paling banyak dibanding kompas.com dan detik.com. Jumlah pelanggaran rata-rata terhadap WCAG pada situs liputan6.com sebanyak 376 item konten sementara kompas.com dan detik.com sebanyak 178 dan 175 item konten.

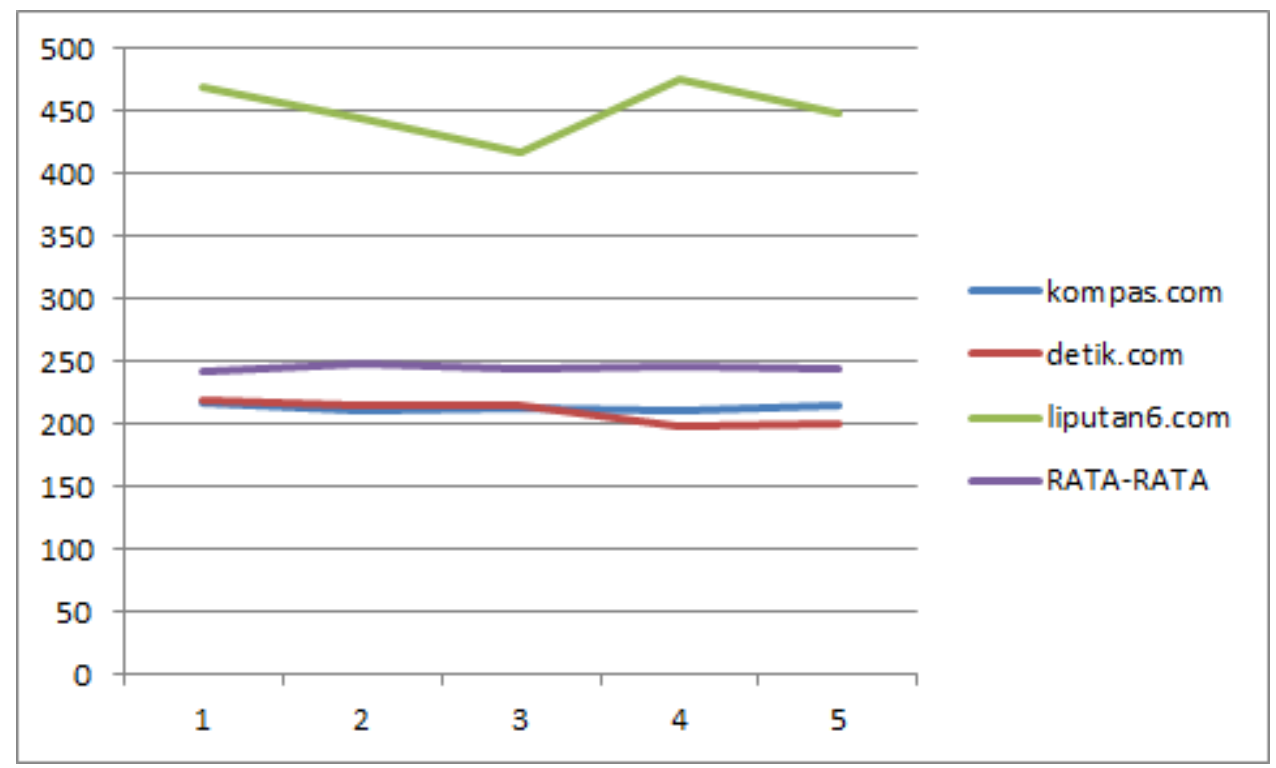

Gambar 4.6. Pelanggaran

Berdasarkan pada kondisi yang terlihat pada gambar 5 dan 6, kompas.com lebih ramah ramah bagi penyandang disabilitas, khususnya tunanetra dan tunarungu, dibanding detik.com dan liputan6.com. Liputan6.com perlu memperbaiki kinerja dengan menyajikan item konten yang sesuai dengan pedoman WCAG sehingga ramah untuk diakses oleh masyarakat difabel.

Kami menekan alasan pemilihan detik.com, kompas.com dan liputan6.com karena tiga situs web ini adalah tiga situs dengan jumlah kunjungan terbanyak atau paling sering diakses. Ketiga situs web ini boleh menyajikan banyak item konten seperti gambar, foto, video dan elemen multimedia lainnya, hanya saja perlu juga dipikirkan bahwa konten yang dimuat harus ramah untuk diakses siapa saja. Berdasarkan analisis yang kami lakukan, liputan6.com adalah situs web media yang belum ramah bagi penyandang disabilitas. 
Gambar 7 menunjukkan hasil yang menarik. Meskipun persentase kesesuaian detik.com berada di atas rata-rata, dalam hal cek manual detik.com adalah yang terbanyak dibanding liputan6.com dan kompas.com. Pada gambar di bawah, terlihat bahwa liputan6.com memiliki jumlah item konten yang harus di cek secara manual paling sedikit dibanding dengan dua media lainnya.

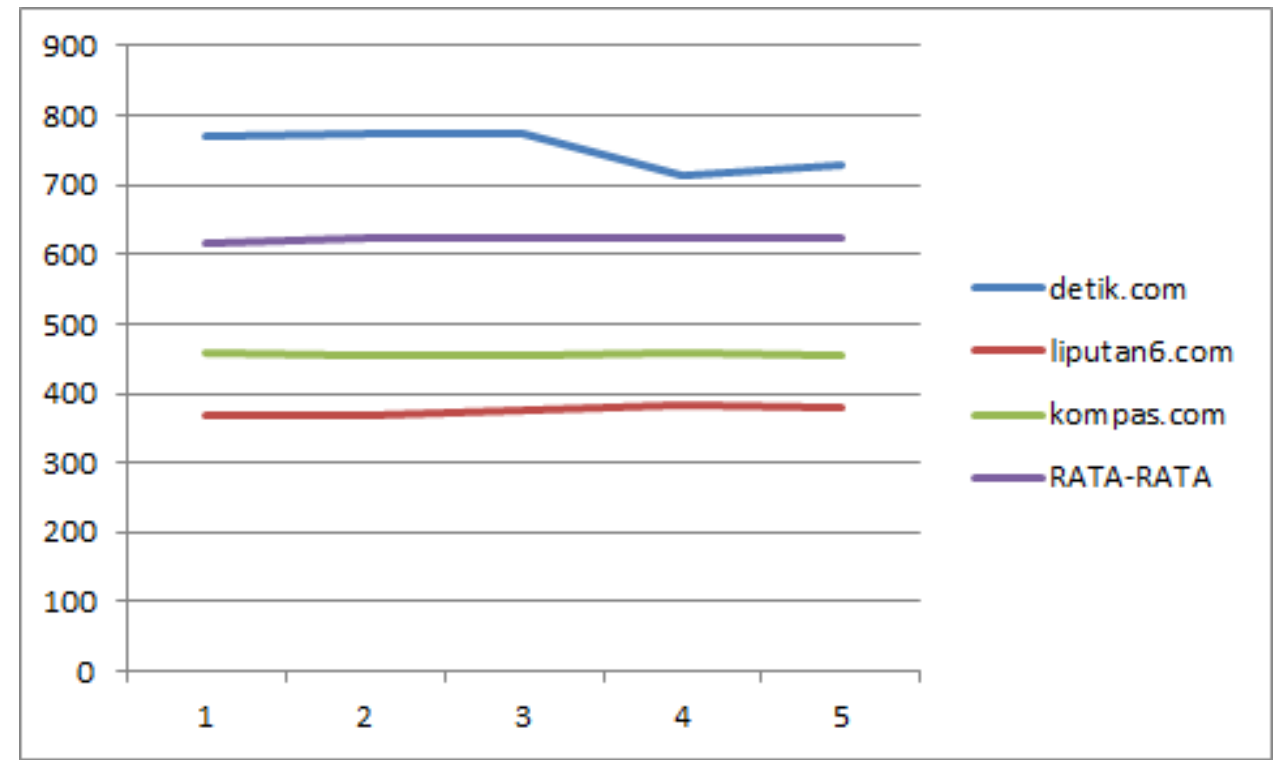

Gambar 4.7 Cek Manual

Jumlah cek manual yang sedikit menunjukkan bahwa penulisan konten pada halaman web tersebut sebagian besar telah sesuai dengan standar W3C dan WCAG. Semakin sedikit jumlahnya tentu saja semakin baik karena evaluasi menjadi lebih mudah dilakukan.

Peneliti tidak bisa secara jelas menyebutkan apakah dengan jumlah item konten cek manual paling sedikit menunjukkan situs tersebut ramah untuk diakses siapa saja sementara yang paling banyak item cek manualnya adalah yang paling buruk. Selalu ada dua kemungkinan dalam hal cek manual, pertama, item konten yang tersaji dalam situs web tersebut eror atau, alasan kedua, item konten yang tersaji dalam situs web tersebut sudah melampaui aturan atau pedoman WCAG.

\section{SIMPULAN}

62 media siber yang telah terverifikasi faktual dan administrasi oleh dewan pers, tidak ada situs web yang $100 \%$ sesuai dengan pedoman WCAG. Angka kesesuaian rata-rata terhadap WCAG tertinggi didapat oleh riau24.com dan manadonews.com dengan nilai kesesuaian kedua sebesar 87,2\%.

Tabloidjubi.com merupakan situs web dengan rata-rata angka kesesuaian terhadap WCAG yang paling rendah dibanding 61 media lainnya. Nilai persentase kesesuaian terhadap WCAG situs web tabloidjubi.com sebesar $28,8 \%$.

Nilai rata-rata kesesuaian terhadap WCAG oleh 62 situs web media sebesar 62,4\%. Angka tersebut menunjukkan bahwa situs web media siber di Indonesia yang telah lulus verifikasi faktual dan aktual belum sepenuhnya ramah bagi penyandang disabilitas, khususnya bagi tunarungu dan tunanetra.

Terdapat 26 situs web media atau sebanyak $42 \%$ dari total yang posisinya berada di bawah rata-rata. Hal ini mengindikasikan perlu adanya peningkatan kualitas item konten yang sesuai dengan pedoman WCAG. Kembali ditekankan, Pedoman Aksesibilitas Konten Web (WCAG) 2.0 yang dijadikan sebagai dasar berpijak dalam penelitian ini mencakup beragam anjuran menyangkut bagaimana membuat konten web menjadi lebih mudah diakses. Jika sebuah situs web mengikuti pedoman WCAG maka konten akan lebih mudah diakses oleh penyandang disabilitas--khususnya tunanetra, tunarungu--dan semakin mudah digunakan oleh pemakai biasa.

Tiga media massa siber yang populer versi alexa.com, yakni, kompas.com, liputan6.com dan detik.com, tidak dalam posisi terbaik. Kompas.com dan detik.com hanya sedikit lebih unggul dari ratarata kesesuaian seluruh media, sedangkan liputan6.com berada jauh di bawah persentase rata-rata kesesuaian. Hal ini menggambarkan meski ketiga media tersebut populer dikalangan masyarakat, 
namun item konten yang tersaji di dalamnya belum ramah sepenuhnya bagi penyandang disabilitas.

Semua situs web yang dianalisis sebenarnya siap untuk diakses oleh publik. Namun, tidak berarti seluruh item konten yang disajikan dalam website tersebut ramah terhadap penyandang disabilitas, tetap butuh fitur tambahan, konfigurasi khusus, maupun alat bantu (assistive technology) untuk memaksimalkan fungsinya.

Berdasarkan hasil penelitian ini, perlu upaya peningkatan kesadaran pengelola media online untuk mengupayakan aksesibilitas bagi penyandang disabilitas. Selain itu, pengembang website juga perlu mendapatkan pemahaman mengenai WCAG dan melibatkan penyandang disabilitas dalam perancangan dan pengujian UX/UI.

\section{DAFTAR PUSTAKA}

BHP UMY. (2015). Hak Penyandang Disabilitas DIY Belum Terpenuhi. Diakses dari http://www.umy.ac.id/hak-penyandang-disabilitas-diy-belum-terpenuhi.html

Cooper, M. (2007). Accessibility of emerging rich web technologies. Proceedings of the 2007 International Cross-Disciplinary Conference on Web Accessibility (W4A) - W4A '07. doi:10.1145/1243441.1243463

Darmasaputra, A., Muqtadiroh, F. A., \& Astuti, H. M. (2016). REKOMENDASI KONTEN WEBSITE JURUSAN DI INSTITUT TEKNOLOGI SEPULUH NOPEMBER BERDASARKAN WCAG 2.0 DAN WEBOMETRICS. SESINDO 2016, 2016

Irwanto, Eva R.K., Asmin F., Mimi L., Okta S. (2010). Analisis Situasi Penyandang Disabilitas Di Indonesia: Sebuah Desk-Review, diakses dari http://www.ilo.org/wcmsp5/groups/public/--asia/---ro-bangkok/---ilo-jakarta/documents/publication/wcms_160340.pdf

Fadhilah, Umi Nur. (2016). Penyandang Disabilitas Kesulitan Akses Informasi Lowongan Kerja, diakses dari http://www.republika.co.id/berita/nasional/umum/16/12/16/oi9mbw359penyandang-disabilitas-kesulitan-akses-informasi-lowongan-kerja

Jaeger, P. T. (2006). Assessing Section 508 compliance on federal e-government Web sites: A multimethod, user-centered evaluation of accessibility for persons with disabilities. Government Information Quarterly, 23(2), 169-190. doi:10.1016/j.giq.2006.03.002

Jaeger, P. T. (2008). User-Centered Policy Evaluations of Section 508 of the Rehabilitation Act. Journal of Disability Policy Studies, 19(1), 24-33. doi:10.1177/1044207308315274

Johnson, B. T., Scott-Sheldon, L. A., Snyder, L. B., Noar, S. M., \& Huedo-Medina, T. B. (2008). Meta-Analysis in Communication Research. The Sage sourcebook of advanced data analysis methods for communication research, 311. Konvensi Hak-Hak Penyandang Disabilitas, diakses dari http://jabar.kemenkumham.go.id/attachments/article/1493/konvensi\%20hakhak\%20penyandang\%20disabilitas.PDF

Mardjianto, F.X. Lilik. (2016). Sudahkah Media "Online” Memenuhi Aksesibilitas Informasi bagi Penyandang Disabilitas? http://nasional.kompas.com/read/2016/ 08/02/08201791/ sudahkah. media. online. memenuhi.aksesibilitas.informasi.bagi.penyandang.disabilitas.

PPDI,(2017). http://www.mediaindonesia.com/news/read/85681/kaum-disabilitas-minta-diperhatikan/ 2017-01-03 Utama, Abraham. (2014). Penyandang Disabilitas Belum Diperhatikan, diakses dari http://www.cnnindonesia.com/nasional/20141203151811-20-15596/penyandangdisabilitas-belum-diperhatikan-media/

Small, J., Schallau, P., Brown, K., \& Appleyard, R. (2005). Web accessibility for people with cognitive disabilities. CHI '05 Extended Abstracts on Human Factors in Computing Systems - CHI '05. doi:10.1145/1056808.1057024

Utami, E. O., Raharjo, S. T., \& Apsari, N. C. (2018). AKSESIBILITAS PENYANDANG TUNADAKSA. Prosiding Penelitian dan Pengabdian kepada Masyarakat, 5(1), 83-101.

Utami, N. W. (2015). Gelap dalam Gemerlap: Gelapnya Akses Informasi Bagi Difabel dalam Gemerlap Era Digitalisasi. CHANNEL Jurnal Komunikasi, 3(2).

Zeng, X., \& Parmanto, B. (2004). Web Content Accessibility of Consumer Health Information Web Sites for People with Disabilities: A Cross Sectional Evaluation. Journal of Medical Internet Research, 6(2), e19. http://doi.org/10.2196/jmir.6.2.e19 